\title{
Downstream Stockpiling of Steel Inventories and Artificial Demand: The Case of Saudi Arabia
}

\author{
Dr. Fadye S. AlFayad \\ Management and Information Technology Department \\ Jubail Industrial College, Saudi Arabia \\ fayad_s@jic.edu.sa
}

\begin{abstract}
This research study has analyzed how downstream stockpiling within the steel industry and its supply channel actually disrupts the efficiency of the supply chain. The premise upon which this study has been approached is one that states that such downstream stockpiling tends to create artificial demand both upstream in the supply chain and in the marketplace. This subject is examined within the context of the Saudi Arabia steel industry and how this type of phenomenon resulted in steel shortages within the Saudi steel market. The study's data found that the Saudi steel market is expected to expand at a compound annual growth rate (CAGR) of some $11.7 \%$ over the next several years. Furthermore, Saudi Arabia has experienced a number of periods of shortages in the supply of steel products. These steel shortages were shown to have resulted in spikes in the price of the commodity for supply chain participants and consumers. The data and information in this study all support the notion that a certain amount of volatility within Saudi Arabia with respect to the steel industry and the supply chain exists. The Kingdom has attempted to compensate for supply chain hoarding and stockpiling by increasing its domestic output which can be utilized to smooth out supply shortages within the supply chain. The study found that the actual result of this rationale in developing buffers is that it quickly transitions into stockpiling. This in turn results in further negative outcomes such as bullwhip effects up and downstream in the supply channel. The information that has been studied revealed that this point at which buffer inventories cross over into what is referred to as hoarding territory can be found through a specific formula. This formula was shown to be the EOQ calculation or the economic order quantity. This calculation utilizes real demand times in the supply chain along with reordering costs divided by the product carrying cost to arrive at an accurate figure. In practice, if the EOQ finds that the annual total steel expense exceeds the annual carrying costs for the inventory then there is excessive inventory or stockpiling in the supply chain. The study has also found that the Saudi Arabia supply chain requires a more efficient way to organize the product flow through the entire steel supply chain. This more efficient methodology would be a supply chain that is organized through the fast-moving, slow-moving and non-moving methodology. This methodology ensures that slow-moving steel products like crude steel, flats and galvanized steel are assigned to the slowmoving category and inventory these items at much lower levels.
\end{abstract}

\section{INTRODUCTION AND OVERVIEW}

This research report examines how downstream stockpiling within the steel industry supply channel disrupts the overall supply chain. The premise that this study is approached with argues that such downstream stockpiling tends to create artificial demand in the marketplace. 
This topic and chief premise is examined within the context of Saudi Arabia and how this phenomenon resulted in what amounts to steel shortages within the Saudi market. Some reports have indicated that the Saudi steel market is expected to expand at a compound annual growth rate (CAGR) of some $11.7 \%$ over the next several years through 2017 at least (Saudi, 2015). Consequently, demand in the Saudi Arabian market for steel already exists in sufficient form to support the health growth of the steel industry.

The premise that this report adopts then which is that downstream stockpiling of steel inventories creates artificial demand, would only aggravate the steel industry. The stockpiling of such inventories occurs within the context of the supply chain for steel in its commodity form. Steel in commodity form typically includes steel ingots, flat sheets, and tubular products as well as finished steel and also scrap steel (de Carvahlo \& Sekiguchi, 2015). These various steel products are subsequently re-used within other industries such as construction, product manufacturing and so forth. As stockpiling takes place in downstream supply chain nodes, the end consumers erroneously believe that there are shortages of steel. The resulting increased demand forces steel prices to increase all the way back up the supply chain to the markets of origin.

\section{The Global Steel Industry}

The steel industry on a global level is one of the most critical commodities and raw materials market in the world. The price of steel, just as with any item, is ultimately governed by the fundamental factors of supply and demand in the marketplace. Artificial manipulation within the context of these two factors may alter the price of steel resulting in spikes and volatility but these two core factors still determine the character of the steel market. In this regard, demand over the prior several years has been estimated to have increased by some 3-4\% because of increased infrastructure buildout throughout many Asia markets and primarily within China (Chen, Yin \& Ma, 2014). Of course, once there is demand in other markets, this in turn utilizes increased amounts of supplies that are available in the marketplace. The result is that despite sufficient productivity of steel products, those markets that have greater demand may be willing to pay more for the supply of steel products.

Suppliers will naturally gravitate to the highest paying marketplace regardless of existing supply chain relationships. The result, unless steel producing markets are able to pick up production, is decreasing levels of steel which itself places upward pressure on the price of the commodity. Equilibrium is reached within the steel industry when steel producers perfectly match production with steel demand by the importing markets such as Saudi Arabia. However, there are no perfect markets and the nature of the global supply chain for steel ensures that numerous variables exist which interfere with the efficiency of the market even when production meets demand.

\section{The Steel Industry in Saudi Arabia}

The demand for steel within Saudi Arabia is driven primarily by its construction and public services infrastructure projects. Saudi Arabia relies on an economy that is driven by its petroleum industry but the steel industry is the physical expression of this economic framework because construction is what the country does with its petroleum revenues. Recent estimates have placed the Kingdom's overall steel consumption at an approximate 16 million tons annually of which some nine million are produced domestically but even this domestic production relies on the importation of raw materials (Saudi, 2015). Large, public infrastructure projects targeted over the next few years ensures that steel imports will continue to be extremely important for the Kingdom. The result is that the anticipated CAGR for steel consumption is expected to mirror this consumption. Some analysts place this CAGR 
estimation in the range of $19.5 \%$ but fluctuation in the supply of steel products can affect the final estimate (Saudi, 2015). One segment within the overall steel industry that is believed to mirror this anticipated growth is the segment for long steel products.

These are long steel products such as rebar supplies, steel bars for construction, various wire products and rods for both transportation and construction. The steel industry in Saudi Arabia continues to diversify over time. Over the past decade or so the Saudi government has been investing a considerable amount of resources into its domestic production of steel supplies. It has fostered this domestic production by providing funding and economic assistance to domestic firms that have the expertise in steel smelting and processing capabilities:

One of the proposed plants is a plate mill...the mill will have a capacity of 1.5 million $\mathrm{t} / \mathrm{y}$ and will house a direct reduced iron facility...The second project is a cold mill...The product slate will include 150,000 t/y of coldrolled products and automotive sheets, 350,000 t/y of hot-dip galvanised steel sheets and 350,000 t/y of tin plate product. (Baxter, 2014, p.9)

Clearly, existing steel production facilities combined with these proposed steel production facilities are aimed at injecting some independence into Saudi Arabia's steel dependence on the international markets. Furthermore, this passage works to illustrate the diversity of steel products that the Kingdom has to accommodate within the steel supply chain both domestically and internationally as well.

The shift to domestic production may not have provided Saudi Arabia with immediate steel independence but it is certainly on that path. Still, considering the Kingdom's position globally as a major steel commodities importer, complete independence in the steel industry is unlikely. The figure below lists the largest steel importing markets globally which works to place Saudi Arabia within the context of the global steel market:

Figure 1: List of Top Steel Importers

\begin{tabular}{|c|l|r|}
\hline Rank & \multicolumn{1}{|c|}{$\begin{array}{c}\text { Net Imports } \\
\text { (imports - exports) }\end{array}$} & Mt \\
\hline 1 & Urited States & 17.8 \\
\hline 2 & Thailand & 14.4 \\
\hline 3 & Indonesia & 11.6 \\
\hline 4 & Vietnam & 8.6 \\
\hline 5 & Saudi Arabia & 6.4 \\
\hline 6 & Urited Arab Emirates & 5.3 \\
\hline 7 & Algeria & 5.1 \\
\hline 8 & Philippines & 4.8 \\
\hline 9 & Irsa & 4.5 \\
\hline 10 & Egypt & 3.9 \\
\hline 11 & Singapore & 3.9 \\
\hline 12 & Hong Kong & 3.2 \\
\hline 13 & Canada & 3.1 \\
\hline 14 & Poland & 3.1 \\
\hline 15 & Iran & 2.7 \\
\hline
\end{tabular}

(World, 2014, p.25)

As the figure demonstrates, Saudi Arabia is the 5th largest importer of raw and finished steel imports globally. This level of steel importation within the country confirms the fact that it is experiencing a substantial amount of economic growth and activity. 


\section{Steel Shortages in Saudi Arabia}

Saudi Arabia has experienced a number of periods of steel supply shortages over the past 5-10 years or so. These types of steel shortages work to create spikes in the price of the commodity for consumers such as construction firms and product manufacturers that depend on finished steel in short, long or roll form. The research reveals that in 2008 steel prices spiked due to supply issues but these increases experienced a market correction before 2009 and by 2012 long steel supplies into the Kingdom dropped by 10\% year-on-year (Durmus, 2013). Consequently, the data and information all point to a degree of volatility within Saudi Arabia with respect to steel in its various forms. The Kingdom has attempted to compensate for this volatility in one form or another. The rationale behind this domestic production is that any increase in domestic output can be utilized to smooth out supply shortages on the open market for unfinished and finished steel commodities.

Domestic steel production itself amounts to an infrastructure commitment on the part of the Saudi government and also contributes to demand. Thus, there has even been a comprehensive effort supported by the Saudi government to improve its domestic production of steel supplies. In fact, the data available demonstrates that Saudi Arabia actually increased its overall steel production some 15\% to about 6.29 million metric tons during 2014 (Regional, 2015). Since the Kingdom's domestic steel production improved by some 15\% from 2013 to 2014, its steel importers were able to accommodate international fluctuations in availability. These fluctuations arise from supply chain and distribution factors relating to demand in other markets such as China which has been demanding ever greater percentages of steel supplies. The Kingdom has, in fact, managed to improve its domestic steel production by another $5.4 \%$ during 2015 thus far as evidenced in the table below:

Table 1: Regional Domestic Steel Production for 2015

\begin{tabular}{|l|l|}
\hline & Percentage change \\
\hline Iran & 15,442 \\
\hline Qatar & 2,236 \\
\hline Saudi Arabia & 5,471 \\
\hline UAE & 2,878 \\
\hline Algeria & 417 \\
\hline Egypt & 6,754 \\
\hline Libya & 712 \\
\hline Morocco & 558 \\
\hline
\end{tabular}

(Regional, 2015)

Iran and Egypt are the only other two Middle Eastern markets that managed to out-produce Saudi Arabia's domestic production levels of steel. Given Egypt's ongoing political and economic issues, it is not unexpected that Saudi Arabia is likely to surpass Egypt's domestic steel production in the near future.

\section{Hoarding, Stockpiling and Shortages}

The steel market in Saudi Arabia is subject to a number of different supply chain reactions which affect the availability and thus the price of the commodity. While Saudi Arabia has done much to improve its domestic production of steel it remains a net importer of the commodity. Therefore, many of the supply chain participants both internationally and domestically are prone to hoarding and stockpiling steel products which simply refers to holding onto excess inventories in the anticipation that future supplies may be difficult to come by(Cho \& Lee, 2013). Initially, this might seem to make reasonable business sense but the effect of this type of 
hoarding and stockpiling activity is to create downstream effects that interfere with the efficiency of the entire supply chain. All supply chain participants depend upon the accurate calculation of an economic order quantity or EOQ. The EOQ is a calculation which is founded upon the idea that the demand for a commodity is predictable, the commodity lead-time within the supply chain is known and that there is little variation along the supply chain (Chen, Cardenas-Barron \& Teng, 2014). Developing an accurate EOQ model forms the nucleus of efficient supply chain management.

In those instances where an accurate or reliable EOQ is not fully developed, there are negative consequences within the supply chain. These negative consequences result in the tendency for supply chain participants to undertake strategies such as hoarding or stockpiling inventories which goes on to result in even more unpredictability in the supply chain. One such unpredictable event that results from these reactions is the bullwhip effect in which large and dramatic swings in the supplies of steel whip up and down the supply chain making it almost impossible to accurately forecast future demand and to efficiently meet current demand (Mehdi \& Farahani, 2014). While there is always a degree of uncertainty within the supply chain, the recognition that hoarding and stockpiling of a commodity is a negative must be understood by all supply chain participants. An accurate and reliable EOQ is one that accounts for proper lead-times and that is based on actual market demand rather than supplier paranoia regarding future inventory availability. In essence, many of the steel industry supply chain participants for Saudi Arabia have developed EOQs that have built in inventory reserves or buffers:

Figure 2: EOQ Calculation Identifying Hoarding/Stockpiling $\mathrm{EOQ}=\sqrt{\frac{2 * \text { Demand } * \text { Re-order.Cost }}{\text { Carrying Cost }}}$

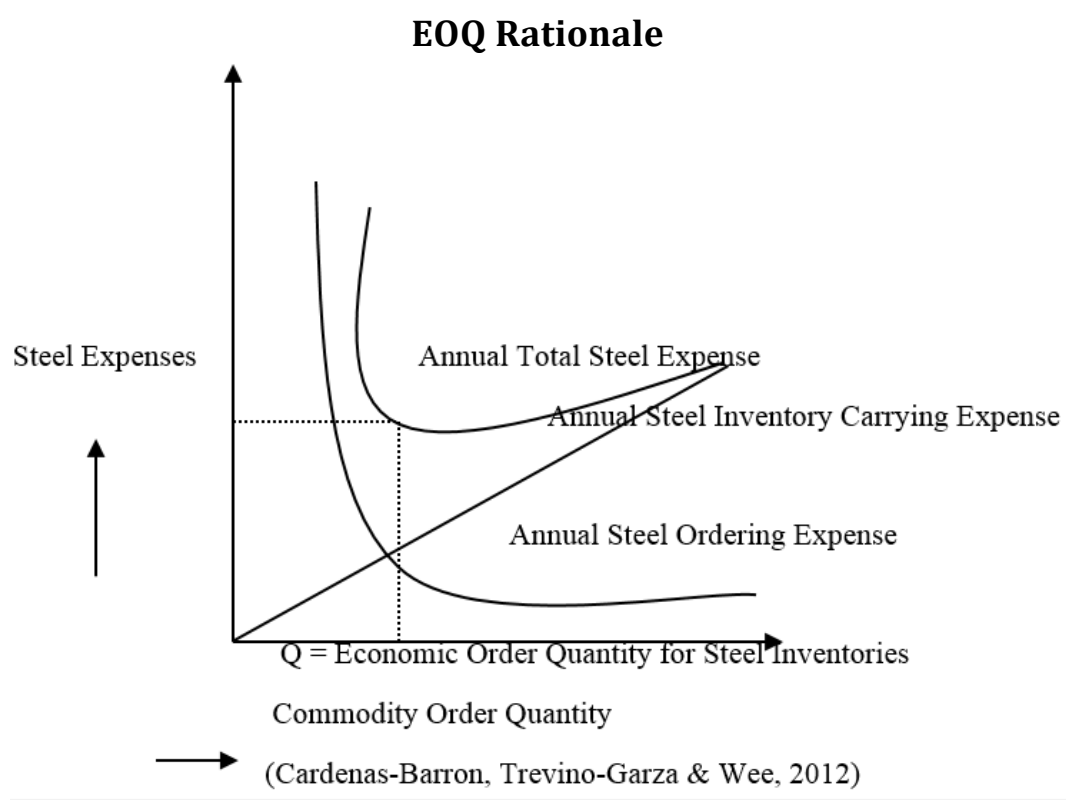

The underlying rationale behind this type of EOQ calculation by the Kingdom's steel suppliers and other supply chain participants is understandable to a point.

Developing a buffer supply of steel does allow these participants to smooth out product shortages in the supply chain. However, the actual result of this rationale is independent 
supply chain participants all developing buffer inventories in an uncoordinated manner that results in bullwhip effects up and downstream in the supply channel. The development of buffer inventories is an effort by supply chain participants to inject certainty back into what some participants believe to be an uncertain market. This problem with this type of approach is that uncertainty itself is difficult to quantify accurately. The result is that developing accurate EOQ models that have built in downstream buffer inventories usually results in undue hoarding and stockpiling which actually contributes to artificial demand back up the supply chain (Chen, Cardenas-Barron \& Teng, 2014). There are analytical methods that can be applied to buffer inventories accurately but these all function on the assumption that the given commodity market is functioning rationally.

Commodities are subject to a number of different external market influences that can affect how product is moved up and down the supply chain. Hence, supply chain participants have to be aware of not only how product is being moved, the cost of this movement and proper forecasting techniques but they also must be aware of what inventories are being carried up and down the supply chain. The practice of hoarding inventories is inherently irrational in its approach regardless of the statistical analysis applied to develop the underlying forecasting models that might be used to justify such activity. Hoarding usually occurs then in the following conceptual manner:

Figure 3: Hoarding Rationale for Buffer Inventories

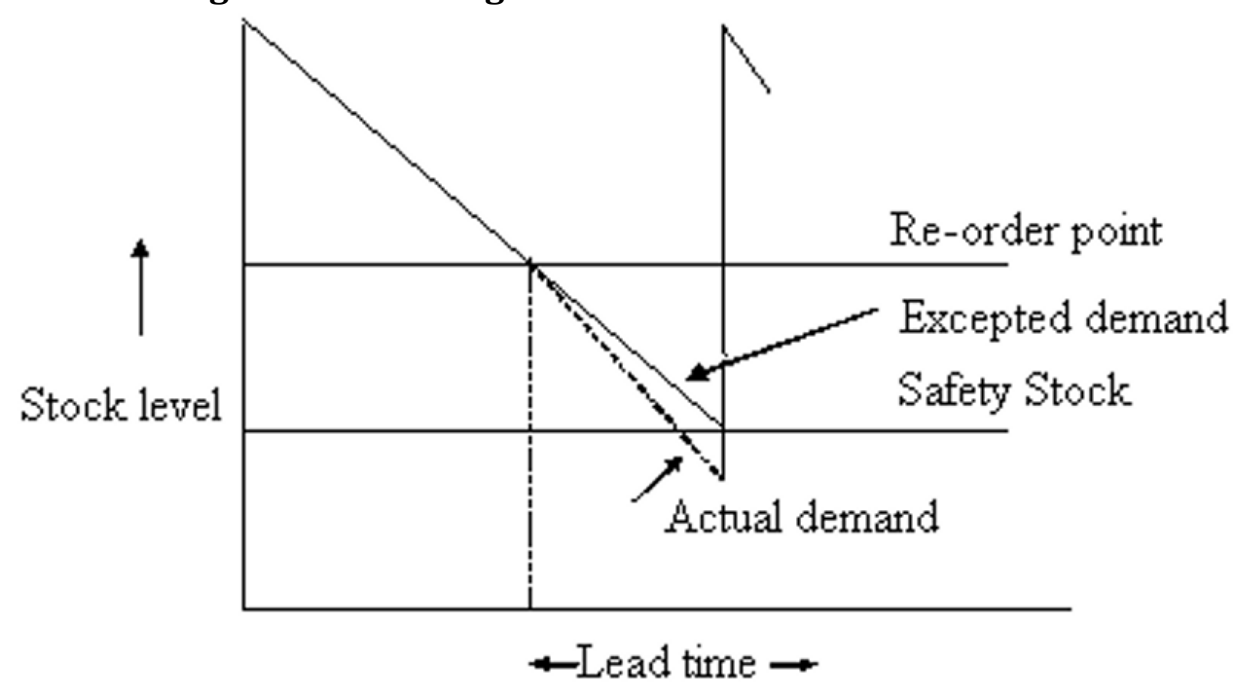

(Croson, Donohue, Katok \& Sterman, 2013)

Buffer inventories are usually calculated by factoring the maximum acceptable product leadtime and the commodity's normal lead-times within the supply channel with demand. On the surface, such buffer inventories or hoarding can positively impact customer service quality because availability is improved at the final supply chain link.

However, eventually this hoarding works its way back up the supply chain and these wide fluctuations in supply will whip back downstream resulting in price volatility. This is where developing an accurate EOQ model that accounts both for forecast demand and market uncertainty is critical to the efficiency of the supply chain for steel products. An accurate EOQ model that accomplishes these outcomes allows supply chain participants to minimize their steel product orders, buffer inventories and hence reduces their overall inventory carrying expenses (Widyadana \& Cardenas-Barron, 2011). Consequently, a more predictable EOQ model for steel within the Kingdom that allows for a buffer inventory while resisting hoarding might resemble the following: 
Table 2: EOQ for Saudi Arabia's Steel Supply Chain

\begin{tabular}{|c|c|c|c|c|c|c|c|}
\hline $\begin{array}{l}\text { Steel } \\
\text { Prod } \\
\text { ucts }\end{array}$ & $\begin{array}{l}\text { Types of Steel } \\
\text { Commodities }\end{array}$ & $\begin{array}{c}\text { Dema } \\
\text { nd } \\
\\
\text { Annu } \\
\text { ally }\end{array}$ & $\begin{array}{c}\text { Re-Ordering } \\
\text { Expense }\end{array}$ & $\begin{array}{l}\text { Carrying Expense by } \\
\text { steel unit/year }\end{array}$ & $\begin{array}{l}\text { EOQ for } \\
\text { Steel }\end{array}$ & $\begin{array}{c}\text { Overall \# of units } \\
\text { Ordered }\end{array}$ & $\begin{array}{c}\text { Overall \# of uni } \\
\text { ordered } \\
\text { annually }\end{array}$ \\
\hline 1. & Blanks & $\begin{array}{c}3,60,2 \\
00\end{array}$ & 12,220 & 2 & $66,272.17$ & 30,200 & 5.43 \\
\hline 2. & Coils & $\begin{array}{c}48,20 \\
0\end{array}$ & 6,220 & 2 & $17,251.09$ & 4,200 & 2.78 \\
\hline 3. & Bars & $\begin{array}{c}1,44,2 \\
00\end{array}$ & 1,720 & 36 & $3,687.82$ & 12,200 & 39.05 \\
\hline 4. & Crude Steel & $\begin{array}{c}96,20 \\
0\end{array}$ & 1,720 & 36 & $3,011.09$ & 8,200 & 31.88 \\
\hline 5. & Flats & $\begin{array}{c}2,40,2 \\
00\end{array}$ & 1,720 & 36 & $4,760.95$ & 20,200 & 50.41 \\
\hline 6. & Galvanized & $\begin{array}{c}30,20 \\
0\end{array}$ & 1,720 & 2 & $7,141.43$ & 2,520 & 4.20 \\
\hline 7. & Longs & $\begin{array}{c}42,20 \\
0\end{array}$ & 1,720 & 2 & $8,449.85$ & 3,520 & 4.97 \\
\hline 8. & Plates & $\begin{array}{c}21,62 \\
0\end{array}$ & 4,720 & 2 & $10,075.71$ & 1,820 & 2.14 \\
\hline 9. & Slabs & 9,620 & 6,220 & 2 & $7,714.92$ & 820 & 1.24 \\
\hline 10. & Strips & $\begin{array}{c}3,60,2 \\
00\end{array}$ & 6,220 & 2 & $47,244.05$ & 30,200 & 7.62 \\
\hline
\end{tabular}

*Pro-forma Estimates

This data in the previous table represent an EOQ model that accounts for an estimated overall inventory that is ordered annually by the Kingdom's supply chain participants. This EOQ figure is factored in relation to other data such as reordering costs, demand and regular order quantities.

The result is that the level of overall variation within the supply chain regarding inventories and demand forecasted is identified. This in turn results in the recognition that downstream hoarding is taking place and that this stockpiling undermines upstream efficiency. A more rational approach to developing practical buffer inventories within the Kingdom's steel supply channel and remove upstream uncertainty is shown in the table below: 
Table 3: Stable Buffer Inventories in Steel

\begin{tabular}{|c|l|c|c|c|c|}
\hline $\begin{array}{c}\text { Steel } \\
\text { Produc } \\
\mathbf{t}\end{array}$ & $\begin{array}{c}\text { Types of Steel } \\
\text { Commodities }\end{array}$ & $\begin{array}{c}\text { Maximum Steel Lead } \\
\text { Times }\end{array}$ & $\begin{array}{c}\text { Normal Steel Lead } \\
\text { Times }\end{array}$ & $\begin{array}{c}\text { Forecast } \\
\text { Demand }\end{array}$ & $\begin{array}{c}\text { Buffer } \\
\text { Inventories }\end{array}$ \\
\hline 1. & Blanks & 0.90 & .30 & $3,60,200$ & 37,440 \\
\hline 2. & Coils & 0.90 & .30 & 48,200 & 4,992 \\
\hline 3. & Bars & 0.90 & .30 & $1,44,200$ & 14,976 \\
\hline 4. & Crude Steel & 0.90 & .30 & 96,200 & 9,984 \\
\hline 5. & Flats & 0.90 & .30 & $2,40,200$ & 24,960 \\
\hline 6. & Galvanized & 0.90 & .30 & 30,200 & 3,120 \\
\hline 7. & Longs & 0.90 & .30 & 42,200 & 4,368 \\
\hline 8. & Plates & 0.90 & .30 & 21,620 & $2,246.4$ \\
\hline 9. & Slabs & 0.90 & .30 & 9,620 & 998.4 \\
\hline 10. & Strips & 0.90 & .30 & $3,60,200$ & 37,440 \\
\hline
\end{tabular}

*Pro-forma Estimates

The data in the previous table illustrates more predictable and rationale buffer inventories for steel within the supply chain by product. Lead-times for each primary steel product is calculated utilizing both annual estimates as well as 90 day and 60 increments due to shipping, transportation and logistical factors within the supply chain. This type of formula ensures that each supply chain participant is permitted to build a buffer inventory but in a way that does not result in bullwhip effects upstream in the supply chain.

\section{DISCUSSION AND ANALYSIS}

The observation is such that downstream stockpiling is an inefficient use of capital within the supply chain. Hoarding and stockpiling are reflections of a lack of capital justification within inventory management in the supply chain. Essentially, steel inventories in the downstream supply chain and, indeed, all along the supply chain, must be arrived at rationally. This is accomplished as a measure of commodity sales in which inventories reflect the ratio of overall steel sales as a measure of the average steel inventories at all points along the supply chain (Lev, 2013). Hence, inventory practices within the steel supply chain must be governed by financial policies as well. These are policies in which calculations such as steel product turnover is measured in all meaningful accounting periods in the financial calendar. This financial imperative in determining efficient steel downstream steel inventory levels is displayed below: 
Table 4: Velocity of Steel Product Turnover Ratios

\begin{tabular}{|c|c|c|c|c|}
\hline Year & Net Steel Sales & $\begin{array}{c}\text { Average Steel Inventory Levels } \\
\text { Predicted Ratio }\end{array}$ & $\begin{array}{c}\text { Product Velocity } \\
\text { Shown in \# of Days }\end{array}$ \\
\hline 2015 & $12,40,05,144$ & $8,42,09,471$ & $1.46: 1$ & 250 \\
\hline 2016 & $16,06,44,669$ & $8,92,28,407$ & $1.80: 1$ & 204 \\
\hline 2017 & $11,74,40,581$ & $14,52,26,925$ & $0.80: 1$ & 456 \\
\hline 2018 & $55,54,74,571$ & $18,98,24,481$ & $2.92: 1$ & 125 \\
\hline 2019 & $79,11,78,220$ & $17,40,71,614$ & $4.5: 1$ & 81 \\
\hline
\end{tabular}

*Pro-forma Estimates

This analysis of lead-times with more rational buffer inventory forecasting techniques demonstrates that some inventory build-up is acceptable.

The trend estimates for the Kingdom indicate that steel imports are almost certain to continue to grow over the next five years. This expected steel import growth will occur despite the increase the Kingdom's domestic steel production which accounts for a slight decline in overall imports but does not radically alter the growth trend (See Appendix 1). Primarily, buffer inventory levels within the steel supply chain should not interfere with market-driven pricing in the steel commodities industry. Whatever levels that the downstream buffer inventories are set at, these should always be such that excess inventories could be converted into customer sales within a relatively brief period of time.

\section{Calculating Downstream Inventories}

Part of the steel forecasting process is to account not just for end-demand in the marketplace but also to account for buffer inventory carrying levels. One approach to achieve this level of inventory sophistication without resulting in irrational hoarding and stockpiling is to utilize regression as a form of forecasting tool. The concept of regressing data implies a degree of dependence of one factor upon the relative independence of another factor which is typically demonstrated through the $X$ and $Y$ variables (Lev, 2013). This analytical process of regressing forecast demand, real demand and inventories is presented below:

Figure 4: Analytics in Regressing for Demand

$$
\mathrm{Y}=\mathrm{a}+\mathrm{bx}
$$

$$
\text { In which } \mathrm{a}=\mathrm{y}-\mathrm{b} x ; \quad \text { and } \quad \mathrm{b}=\underline{\Sigma x y-n x \bar{y}}
$$

$$
\Sigma \mathrm{x}^{2}-\mathrm{nx} \mathrm{x}^{2}
$$

Accordingly, the result of this particular regression of inventories and demand ensures that supply chain participants would be supported in gradually increasing buffer inventories. This type of approach to market uncertainly is demonstrated in the following table: 
Table 5: Downstream Buffer Inventory Build-up

\begin{tabular}{|c|c|c|c|c|}
\hline \multirow{2}{*}{ Inventory Years } & $\begin{array}{c}\text { Buffer Inventories } \\
\text { Shown as Rs \& Y }\end{array}$ & $\begin{array}{c}\mathbf{X} \\
\mathbf{X = x - 2 2 1 9}\end{array}$ & $\mathbf{X}^{\mathbf{2}}$ & $\begin{array}{c}\text { XY } \\
\mathbf{\&}(\mathbf{R s})\end{array}$ \\
\hline 2015 & $9,17,88,514$ & -2 & 4 & $-18,35,77,228$ \\
\hline 2016 & $8,66,68,32$ & -1 & 1 & $-8,66,68,32$ \\
\hline 2017 & $22,37,85,552$ & 2 & 1 & 2 \\
\hline 2018 & $17,58,61,213$ & 1 & 4 & $34,45,64,228$ \\
\hline 2019 & $17,22,82,214$ & 2 & $\mathbf{1 2}$ & $\mathbf{2 5 , 2 1 , 7 9 , 9 1 3}$ \\
\hline
\end{tabular}

*Pro-forma Estimates

Where the following regression is applied to the predicted inventory levels and forecasted steel demand in the Saudi marketplace:

Figure 5: Regressing Inventories and Demand

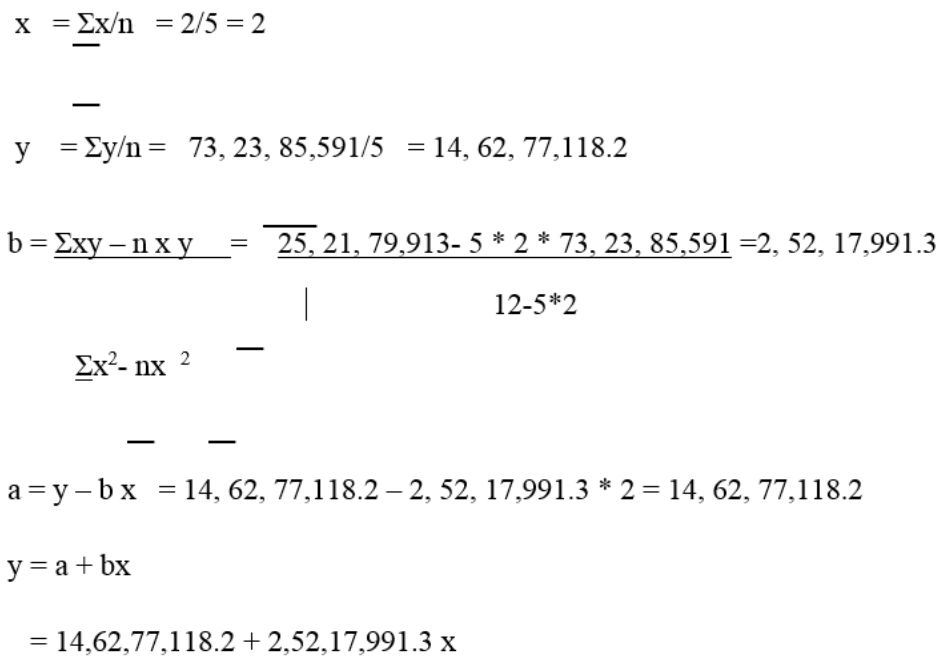

According to the regression analysis, there is a reliable point in the data in which steel buffer inventories are allowed to increase as a reflection of uncertainty. Yet, this is accomplished over a more manageable period of time which is not reflective of a knee-jerk reaction in the marketplace to uncertainty. This approach removes the threat of upstream bullwhip effects due to downstream stockpiling based on independent paranoia regarding inventory levels.

\section{CONCLUSIONS AND OBSERVATIONS}

This report examined the question of whether downstream stockpiling or hoarding of steel inventories within the supply chain negatively affected upstream inventories. Specifically, the question is whether or not such downstream hoarding creates artificial demand in the marketplace with respect to the Saudi Arabian market. The report identified the steel industry and the supply chain that supports it as consisting of steel products including rolls, sheets, blanks, ingots, longs and shorts and so on. The Saudi Arabian market has been increasing its imports of steel products for many years in order to support the infrastructure buildout and construction industry in the market that has been expanding rapidly over the past decade or so. The research demonstrated how the Saudi government has been responding to this downstream stockpiling and the artificial upstream demand that it creates. The Saudi 
government has been fostering the growth of the Kingdom's own domestic steel producing industry for a number of years. With the Kingdom's current domestic steel production which provides over half of its steel needs at current demand and the planned establishment of several new steel plants that will add over 2 million metric tons of annual production to the market, Saudi Arabia will bolster its domestic production even further.

The Kingdom should be able to eventually remove the incentive that downstream suppliers have to hoard steel products despite the lack of a true stimulus to do so. Hence, the findings indicate that what the Kingdom's steel industry really needs is a more efficient means to manage its steel industry supply channel. One effective means of determining the most efficient approach to managing a supply chain is the fast-moving, slow-moving and non-moving or FSN process. The FSN process allows the supply chain participant to structure the supply chain in a way that reflects the individual demand for each product item rather than for the product class itself. Hence, the FSN approach assigns priority to those steel products that have greater demand and therefore move faster compared to those steel products that have less demand and therefore move slower and these two divisions in turn are differentiated from those steel products that manifest little or no movement (Vrat, 2014). It is essential to be able to differentiate steel products based on this characteristic of movement because steel is a commodity that does fluctuate based on productivity, supply chain factors and downstream hoarding and so forth. This approach to the steel supply chain servicing Saudi Arabia can be formulated in the following manner:

Table 6: Fast/Slow/Non-Moving Steel Products

\begin{tabular}{|l|l|l|}
\hline Fast-Moving & Slow-Moving & Non-Moving \\
\hline Coils & Plates & Crude \\
\hline Bars & Slabs & \\
\hline Flats & Strips & \\
\hline Longs & Blanks & \\
\hline Galvanized & & \\
\hline
\end{tabular}

The table above identifies those faster-moving steel products which are some $50 \%$ of the steel products that dominate the Saudi steel supply chain. The crude steel products tend to be nonmovers in the Saudi marketplace because they require special processing before they can even be integrated into the production, manufacturing or construction industries.

The data demonstrated that Saudi Arabia has experienced periods of price volatility in the steel market. These periods are a reflection of supplier and distributor uncertainty more than any actual product shortage in the international marketplace. For instance, in 2008 prices of steel did spike but there was not an actual shortage of steel products but instead this was due more to the logistical capacity of suppliers to move steel products to other markets versus Saudi Arabia. Once the supply channel began to adapt to this logistical feature in the supply chain, steel prices dropped between 2009 and 2012 by $10 \%$ annually. Simply put, it was easier for suppliers to move steel products into other markets who had the same demand level but who also were logistically easier to ship into such as China with its vast network of bulk shipment ports and intermodal waterways. Hence, the immediate knee-jerk reaction on the part of suppliers within Saudi Arabia's steel industry was to begin to stockpile reserves once supply 
access recovered. While some buffer inventory is useful and, indeed, preferred, there is a point at which a buffer inventory shifts into the area of product hoarding.

The data and analysis revealed that this point at which buffer inventories cross over into hoarding territory can be found through a specific formula. This formula was shown to be the EOQ calculation which utilizes real demand times re-ordering costs divided by the product carrying cost. At any rate, if the annual total steel expense exceeds the annual carrying costs for the inventory then there is excessive inventory or stockpiling. This may not occur year around but there would be points throughout the year at which more steel products are ordered than are distributed which is indicative of hoarding. Therefore, an improved EOQ process that eliminates the opportunity for independent supply chain operators to hoard and stockpile inventory would be quite useful. This would act to free up supply chain operator capital that could be redirected towards improving operational efficiency. An improved EOQ framework would allow supply chain operators to maintain some buffer inventory for steel products but these would be limited in scale. Efficiency could be further improved within the supply chain by focusing on those steel products that tend to move faster versus those that are slow moving.

Additionally, there should be a more efficient way to organize the product flow through the entire supply chain. This more efficient methodology would be a supply chain that is organized through the FSN method. With steel products such as crude steel, flats and galvanized steel moving in fewer quantities than other steel products but having a higher carrying cost, it makes sense to assign these steel products to the slow-moving category and inventory these items at much lower levels. However, the regression of the data indicated that such products as flats were forecasted to increase due to the expansion of infrastructure projects in the Kingdom and thus it would be transferred to the fast-moving category within the FSN framework. The point is that the number of days in inventory for each individual steel product should be reduced to the shortest period that is possible without completely removing all buffer inventories.

Buffer inventories provide the capacity for steel suppliers and distributors to fluctuate product movement in response to both supply and demand whether this supply or demand is artificial in character or not. However, excessive inventories place an immense financial burden on the supply chain operators and, ultimately, create artificial demand in the upstream supply chain that eventually results in increasing inventories all along the supply chain. This is because this artificial demand is not created by the end consumers who would otherwise remove the steel products from the supply chain at purchase. Essentially, excessive stockpiling and hoarding of inventory creates a kind of iterative ordering process that keeps adding even more products to the inventories of suppliers in the downstream supply chain. By developing a more accurate EOQ calculation based on real market figures and utilizing the FSN approach to supply chain design, the Saudi Arabian steel market would become much more reflective of actual market conditions.

\section{References}

Baxter, K. (2014). Sabic's $\$ 4.2$ bn steel plants put on hold.

MEED: Middle East Economic Digest, 58(29), 9. DOI (Accession Number): 97237982-ISSN 0047-7238

Cárdenas-Barrón, L. E., Treviño-Garza, G., \& Wee, H. M. (2012).

A simple and better algorithm to solve the vendor managed inventory control system of multi-product multiconstraint economic order quantity model. Expert Systems with Applications, 39(3), 3888-3895. DOI: 10.1016/ j.eswa.2011.09.057

Chen, S. C., Cárdenas-Barrón, L. E., \& Teng, J. T. (2014). 
AlFayad, F.S. (2016). Downstream Stockpiling of Steel Inventories and Artificial Demand: The Case of Saudi Arabia. Archives of Business Research, 4(6), 16-29.

Retailer's economic order quantity when the supplier offers conditionally permissible delay in payments link to order quantity. International Journal of Production Economics, 155, 284-291. doi:10.1016/j.ijpe.2013.05.032

Chen, W., Yin, X., \& Ma, D. (2014). A bottom-up analysis of China's iron and steel industrial energy consumption and CO 2 emissions. Applied Energy, 136, 1174-1183. doi:10.1016/j.apenergy.2014.06.002

Cho, D. W., \& Lee, Y. H. (2013). Seasonal supply chain and the bullwhip effect. International Journal of Industrial Engineering, 20(1/2), 188-210. DOI (Accession Number): 86970668-ISSN 1943-670X.

Croson, R., Donohue, K., Katok, E., \& Sterman, J. (2014). Order stability in supply chains: coordination risk and the role of coordination stock.Production and Operations Management, 23(2), 176-196. DOI: 10.1111/j.19375956.2012.01422.x

De Carvalho, A., \& Sekiguchi, N. (2015). The structure of steel exports. OECD Science, Technology and Industry Working Papers, 07(01), pp.1-39. DOI 10.1787/5jrxfmstf0xt-en

Durmus, S. (2013). Steel success strategies: Saudi Arabia demand growing with oil prices, Sabic says. Metal Bulletin Daily, (350), 184. DOI (Accession Number): 85850242-ISSN 2057-2379.

Lev, B. (2013). Economic Order Quantity Model Extensions. Encyclopedia of Operations Research and Management Science, 464-466. DOI 10.1007/978-1-4419-1153-7_269

Najafi, M., \& Farahani, R. Z. (2014). New forecasting insights on the bullwhip effect in a supply chain. IMA Journal of Management Mathematics, 25(3), 259-286. DOI (Accession Number): 96731579-ISSN 1471-678X.

Regional steel is global pacesetter. (2015). MEED: Middle East

Economic Digest, 59(4), 9. DOI (Accession Number): 101077910-ISSN 0047-7238.

Saudi Arabia steel industry outlook 2020. (2015). Research and Markets, 05(19), pp.1-32.

Vrat, P. (2014). Dynamic Inventory Models: Aggregate Analysis.

In Materials Management (pp. 67-79). Springer India. DOI 10.1007/978-81-322-1970-5_5

Widyadana, G. A., Cárdenas-Barrón, L. E., \& Wee, H. M. (2011).

Economic order quantity model for deteriorating items with planned backorder level.Mathematical and Computer Modelling, 54(5), 1569-1575. DOI:10.1016/j.mcm.2011.04.028 